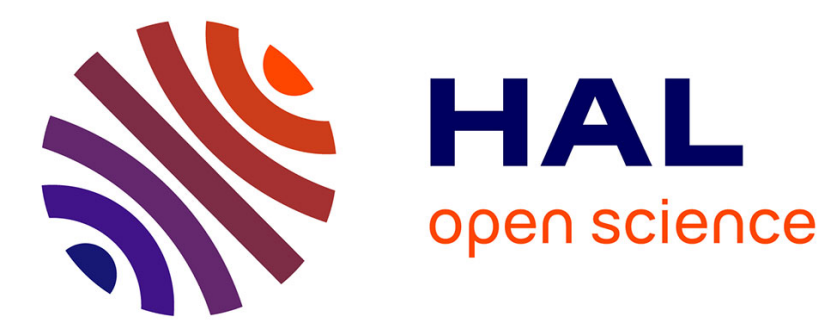

\title{
VORLÄUFIGE ERGEBNISSE AUS DER KREUZUNG VON ROTBUNTEN HOLSTEIN-FRIESIAN MIT FLECKVIEH IN BAYERN
}

\author{
G. Averdunk, A. Gottschalk, H. Kräusslich, E. Schwarz
}

\section{- To cite this version:}

G. Averdunk, A. Gottschalk, H. Kräusslich, E. Schwarz. VORLÄUFIGE ERGEBNISSE AUS DER KREUZUNG VON ROTBUNTEN HOLSTEIN-FRIESIAN MIT FLECKVIEH IN BAYERN. Annales de génétique et de sélection animale, 1975, 7 (2), pp.239-239. hal-00892681

\section{HAL Id: hal-00892681 \\ https://hal.science/hal-00892681}

Submitted on 1 Jan 1975

HAL is a multi-disciplinary open access archive for the deposit and dissemination of scientific research documents, whether they are published or not. The documents may come from teaching and research institutions in France or abroad, or from public or private research centers.
L'archive ouverte pluridisciplinaire HAL, est destinée au dépôt et à la diffusion de documents scientifiques de niveau recherche, publiés ou non, émanant des établissements d'enseignement et de recherche français ou étrangers, des laboratoires publics ou privés. 
In order to utilize these objectives in an optimal way, it is of importance to obtain knowledge about the necessary crossbreeding parameters. In many cases, females of the extraneous breed are not available in the country considered. This makes it difficult to obtain estimates of the needed crossbreeding parameters. By utilizing a modern AI breeding program, however, an experiment can be planned in such a way that crossbreeding parameters of interest can be estimated. The experimental plan necessitates the following steps :

I. Selection of bulls within extraneous populations according to their proves.

2. Importation of semen from the selected bulls.

3. The imported semen doses are inseminated on elite cows in the native breeding population.

4. Young bulls of $F_{1}$ are progeny tested.

5. Young bulls of three-quarter of the extraneous breed are produced by inseminating unselected $F_{1}$-daughters with the imported semen.

6. Young bulls of three-quarter of the extraneous breed are progeny tested.

7. The regular AI breeding programme of the native breeding population yields groups of control.

By utilizing production records of cows with different proportion of the extraneous breed, the data can be used to estimate the following parameters :

I. The difference between the imported bulls of the extraneous breed and the contemporary native elite bulls in general combining ability.

2. The magnitude of the heterotic effect.

Thus, the crossbreeding parameters of actual interest for the native breeding population can be estimated.

\section{VORLÄUFIGE ERGEBNISSE AUS DER KREUZUNG VON ROTBUNTEN HOLSTEIN-FRIESIAN MIT FLECKVIEH IN BAYERN}

G. Averdunk, A. GotTschalk, H. KRäusslich, E. Schwarz. - Bayerische Landesanstalt f. Tierzucht, 8011 Grub b. München (BRD).

Ưber vorläufige Ergebnisse der Leistungen der Kreuzungen von Rotbunten Holstein-Friesian Bullen und Fleckviehkihen wird berichtet. In der I. Laktation zeigten die $F_{1}$-Tiere im Vergleich zu reinrassigen Fleckvieh-Stallgefährtinnen eine Differenz von $+700 \mathrm{~kg}$ Milch, $+25 \mathrm{~kg}$ Fett und - o,05 Prozent Fett. Die gewogene Differenz nach dem Contemporary Comparison war mit + $594 \mathrm{~kg} \mathrm{Milch},+20 \mathrm{~kg}$ Fett und - 0.08 Prozent Fett etwas geringer. Das Erstekalbealter der $\mathrm{F}_{1}$-Tiere war um I.8 Monate niedriger, während die Melkbarkeit, Euterform und Körpergrösse deutlich höher lagen. Die Konformation der Kühe und Bullen war im Hinblick auf die Fleischproduktion negativ beeinflusst.

Die Ergebnisse der Fleischleistungsprüfung an 2 Stationen zeigten bei den $F_{1}$-Bullen eine grössere Frühreife wie bei den Flechviehvergleichsbullen. Bei der Mastprüfung bis zum 50o. Lebenstag hatten die $F_{1}$-Bullen ein um $I_{3} \mathbf{~ k g}$ geringeres Gewicht bzw. ein Unterschied von $34 \mathrm{~g}$ Zunahme im Prüfungsabschnitt vom I I2. - 500. Tag. Auf höherem Zunahmeniveau betrug die Differenz in der Zunahme $67 \mathrm{~g}$. Die $F_{1}$-Schlachtkörper hatten mehr Beckenhöhlen- und Nierenfett (1.4 kg), einen geringeren Pistolenanteil (1.2 Prozent eine geringere Rückenmuskelfläche $\left(8.7 \mathrm{~cm}^{2}\right.$ an 8./9. Rippe) und eine grössere Schlachtkörperlänge $(1.9 \mathrm{~cm})$. Die Schlachtkörper waren auf dem Schlachtviehmarkt weniger akzeptabel und wurden teilweise diskriminiert.

Der relative Anteil von Heterosis an den Leistungsunterschieden der $F_{1}$-Tiere kann zum gegenwärtigen Stand des Versuches noch nicht beurteilt werden.

\section{A SCHEME FOR COMPARISON}

\section{OF DIFFERENT STRAINS OF FRIESIANS}

\section{H. SkJervold. - The Agricultural University of Norway, Aas-NLH, Norway.}

During the last decades large effort has been made in developing efficient breeding schemes in various populations in dairy cattle.

An important part of such breeding schemes is a continuous measuring of achieved genetic 